\title{
From sea ice to seals: a moored marine ecosystem observatory in the Arctic
}

\author{
Claudine Hauri ${ }^{1}$, Seth Danielson ${ }^{2}$, Andrew M. P. McDonnell ${ }^{2}$, Russell R. Hopcroft ${ }^{2}$, Peter Winsor ${ }^{2}$, Peter Shipton ${ }^{2}$, \\ Catherine Lalande $^{3}$, Kathleen M. Stafford ${ }^{4}$, John K. Horne ${ }^{5}$, Lee W. Cooper ${ }^{6}$, Jacqueline M. Grebmeier ${ }^{6}$, \\ Andrew Mahoney ${ }^{7}$, Klara Maisch $^{8}$, Molly McCammon ${ }^{9}$, Hank Statscewich ${ }^{2}$, Andy Sybrandy ${ }^{10}$, and \\ Thomas Weingartner ${ }^{2}$ \\ ${ }^{1}$ International Arctic Research Center, University of Alaska Fairbanks, Fairbanks, AK 99775, USA \\ ${ }^{2}$ College of Fisheries and Ocean Science, University of Alaska Fairbanks, Fairbanks, AK 99775, USA \\ ${ }^{3}$ Département de Biologie, Université Laval, Québec, QC G1V 0A6, Canada \\ ${ }^{4}$ Applied Physics Laboratory, University of Washington, Seattle, WA 98195, USA \\ ${ }^{5}$ School of Aquatic and Fishery Sciences, University of Washington, Seattle, WA 98195, USA \\ ${ }^{6}$ Chesapeake Biological Laboratory, University of Maryland Center for Environmental Science, Solomons, MD 20688, USA \\ ${ }^{7}$ Geophysical Institute, University of Alaska Fairbanks, Fairbanks, AK 99775, USA \\ ${ }^{8}$ Klara Maisch Art and Design, Fairbanks, AK 99775, USA \\ ${ }^{9}$ Alaska Ocean Observing System, Anchorage, AK 99501, USA \\ ${ }^{10}$ Pacific Gyre Inc., Oceanside, CA 92056, USA
}

Correspondence: Claudine Hauri (chauri@alaska.edu)

Received: 11 July 2018 - Discussion started: 8 August 2018

Revised: 31 October 2018 - Accepted: 1 November 2018 - Published: 19 November 2018

\begin{abstract}
Although Arctic marine ecosystems are changing rapidly, year-round monitoring is currently very limited and presents multiple challenges unique to this region. The Chukchi Ecosystem Observatory (CEO) described here uses new sensor technologies to meet needs for continuous, highresolution, and year-round observations across all levels of the ecosystem in the biologically productive and seasonally ice-covered Chukchi Sea off the northwest coast of Alaska. This mooring array records a broad suite of variables that facilitate observations, yielding better understanding of physical, chemical, and biological couplings, phenologies, and the overall state of this Arctic shelf marine ecosystem. While cold temperatures and 8 months of sea ice cover present challenging conditions for the operation of the $\mathrm{CEO}$, this extreme environment also serves as a rigorous test bed for innovative ecosystem monitoring strategies. Here, we present data from the 2015-2016 CEO deployments that provide new perspectives on the seasonal evolution of sea ice, water column structure, and physical properties, annual cycles in nitrate, dissolved oxygen, phytoplankton blooms, and export, zooplankton abundance and vertical migration, the occurrence
\end{abstract}

of Arctic cod, and vocalizations of marine mammals such as bearded seals. These integrated ecosystem observations are being combined with ship-based observations and modeling to produce a time series that documents biological community responses to changing seasonal sea ice and water temperatures while establishing a scientific basis for ecosystem management.

\section{The gateway to the Arctic Ocean}

The Chukchi continental shelf is the seasonally ice-covered entryway of Pacific-origin waters flowing northward into the Arctic Ocean. An oceanic pressure and elevation differential between the Pacific and the Arctic oceans is the driving force for this transport (Stigebrandt, 1984), moving water, heat, nutrients, organic carbon, and organisms northward and leading to transformations on the shelf en route to the deep Arctic Ocean. Large late spring and summertime phytoplankton blooms (Sambrotto et al., 1984; Springer et al., 1996; Arrigo et al., 2014; Hill et al., 2018) make the Chukchi continen- 
tal shelf an extremely productive marine ecosystem that supports a thriving benthos (Grebmeier et al., 2006), zooplankton (Ershova et al., 2015), seabirds (Kuletz et al., 2015), and marine mammals (Hannay et al., 2013).

The Chukchi Sea shelf is part of a broader Arctic system undergoing rapid change. The Arctic near-surface air temperature is increasing almost twice as fast as the global average (Serreze and Francis, 2006; Stocker et al., 2013). On the Chukchi Shelf, annual average sea surface temperatures have been as much as $0.8^{\circ} \mathrm{C}$ warmer during the last 2 decades compared to the average of the 1900-2016 period of record (Smith et al., 2008, Fig. 1). Warming has led to a $>40 \%$ Arctic-wide decrease in summertime sea ice extent over the last 4 decades (Serreze and Stroeve, 2015). In the Chukchi and Beaufort seas, ice cover has decreased by 1.24 days year $^{-1}$ since 1979 , a trend that accelerated to a decrease of 12.84 days year $^{-1}$ in the 2000-2012 period (Frey et al., 2015). The freshwater content of the Arctic Ocean has also increased profoundly since the 1990 s, with potentially large effects on the global thermohaline circulation (McPhee et al., 2009; Proshutinsky et al., 2009). Anticyclonic winds, sea ice melt, increased precipitation, and runoff are suggested to be the contributing factors to the widespread freshening of the Arctic Ocean (McPhee et al., 2009; Morison et al., 2012; Bintanja and Selten, 2014). Pacific Arctic storm frequency and intensity has also increased over the last 25 years (Pickart et al., 2013). This increased storm activity corresponds with wintertime Northern Hemisphere temperature increases, which has likely led to a northward shift of Northern Hemisphere storm tracks (McCabe et al., 2001; Hakkinen et al., 2008). High-latitude marine ecosystems are also particularly vulnerable to ocean acidification (Orr, 2011). Due to naturally lower carbonate ion concentrations $\left[\mathrm{CO}_{3}^{2-}\right]$ and accelerated decrease in $\left[\mathrm{CO}_{3}^{2-}\right]$ as a result of sea ice and glacial melt (Yamamoto-Kawai et al., 2009; Evans et al., 2014), these regions are quickly being pushed closer or past biologically important thresholds. Already today, the consequences of these anthropogenic changes are visible in the marine ecosystem and manifest themselves as species range shifts, changes in abundance, growth, condition, behavior and phenology, and community and regime shifts (Wassmann et al., 2011).

These anthropogenic changes have large implications for the ecosystem and the global carbon cycle and climate. To monitor these changes, disentangle their effects from those caused by natural variability, and improve our mechanistic understanding of the ecosystem dynamics, we designed an observatory capable of continuously recording a broad suite of ecosystem variables in the northeastern Chukchi Sea (Figs. 2-4).

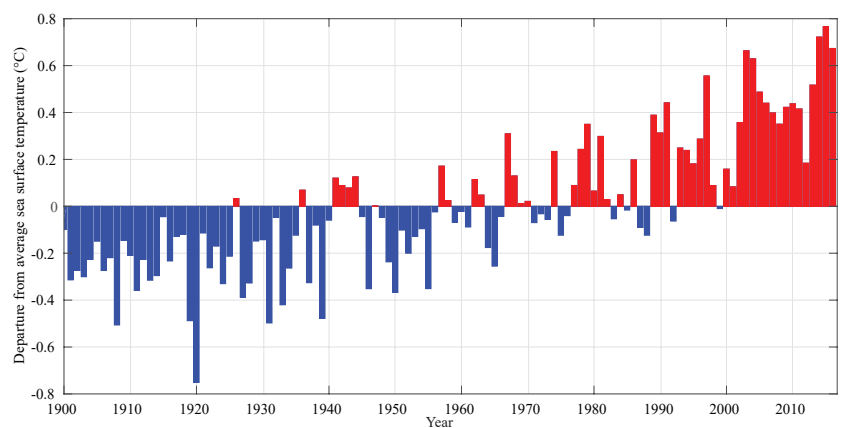

Figure 1. Chukchi Sea continental shelf (64 to $74^{\circ} \mathrm{N}$ and 180 to $157^{\circ} \mathrm{W}$ ) annual sea surface temperature anomaly over the 1900-2016 period of record from the extended reconstructed sea surface temperature (SST) dataset (Smith et al., 2008). The data are publicly available here: https://www.ncdc.noaa.gov/data-access/marineocean-data/ extended-reconstructed-sea-surface-temperature-ersst-v5 (last access: 9 November 2018). Blue bars indicate colder than average temperatures for the given year, whereas red bars indicate warmer than average temperatures. The annual anomalies were computed by subtracting the long-term mean $\left(0.114^{\circ} \mathrm{C}\right)$.

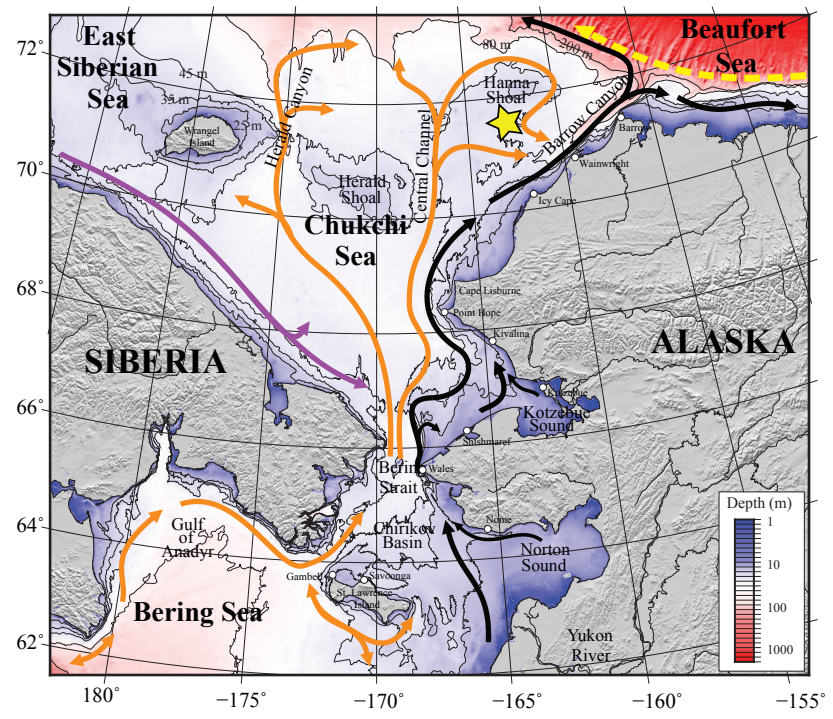

Figure 2. Bathymetry of the Chukchi, northern Bering, East Siberian and eastern Beaufort seas. The Chukchi Ecosystem Observatory (CEO) near Hanna Shoal is marked with a yellow star. General circulation patterns are shown with arrows: black - Alaskan Coastal Water and Alaskan Coastal Current, dividing into the Shelfbreak Jet (right) and Chukchi Slope Current (left, Corlett and Pickart, 2017); orange - Anadyr, Bering Sea, and Chukchi Sea Water; purple - Siberian Coastal Current; yellow - Beaufort Gyre boundary current. "Water" designations were used for locations where persistent currents have not been identified and named yet. 


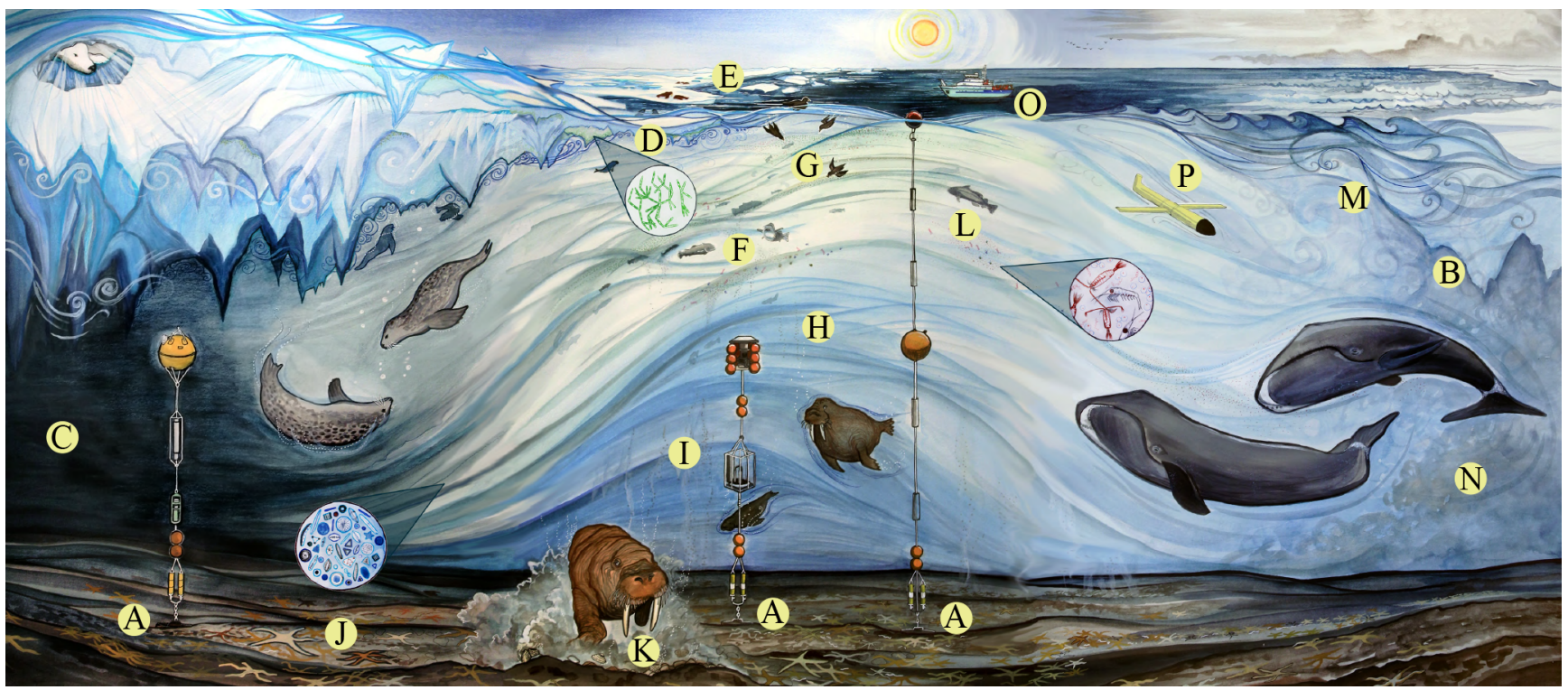

Figure 3. Illustration of the mooring array and the ecosystem at the observatory site. (A) Mooring array, (B) brine rejection, (C) dark winter, (D) sea ice algae bloom, (E) receding sea ice, $(\mathrm{F})$ phytoplankton bloom, $(\mathrm{G})$ stratification, $(\mathrm{H})$ vertical gradient of nutrients and inorganic carbon, (I) sinking particulate organic matter, (J) rich benthic ecosystem, (K) foraging walrus, (L) Arctic cod, (M) storm-induced mixing, (N) senescent planktonic ecosystem, (O) Research Vessel Sikuliaq, and (P) glider. The illustration was painted by Klara Maisch. A high-resolution version can be downloaded from her personal website at https://klaramaisch.com/chukchi-sea-mooring-illustration (last access: 9 November 2018). Examples of walrus and bearded seal sounds are available at http://mather.sfos.uaf.edu/ seth/CEO/Sounds.html (last access: 9 November 2018). A movie describing the observatory in more detail is available at https://www.youtube.com/watch? $\mathrm{v}=$ ypmzTuAQ98k\&feature=youtu.be (last access: 9 November 2018).

\section{The Chukchi Ecosystem Observatory}

The CEO is an array of closely colocated subsurface moorings in the northeast Chukchi Sea $\left(71^{\circ} 35.976^{\prime} \mathrm{N}\right.$, $161^{\circ} 31.621^{\prime}$ W; Figs. 2-4; https://www.youtube.com/watch? v=ypmzTuAQ98k\&feature=youtu.be, last access: 9 November 2018). The CEO is situated in $45 \mathrm{~m}$ of water on the southeastern flank of Hanna Shoal within a productive biological "hotspot" (Grebmeier et al., 2015). The shoal's shallow depths result in deep ice keel groundings (Barrett and Stringer, 1978) and the accumulation of thick ice, which serves as an important habitat for walrus and other animals (Jay et al., 2012). The exact observatory siting and our ecological understanding of the greater region are based on many years of multidisciplinary sampling on the NE Chukchi Shelf, including those of the Chukchi Sea Environmental Studies Program (Day et al., 2013), the Chukchi Offshore Monitoring in Drilling Area (Dunton et al., 2014), and the Distributed Biological Observatory (DBO; Moore and Grebmeier, 2018).

The CEO moorings carry sensors that collectively measure an extensive suite of physical, biogeochemical, and biological variables (Fig. 4). These sensors allow us to observe and understand the phenology and connections within this Arctic marine ecosystem. The sensors capture temporal variations in sea ice cover and thickness, light, currents, waves, water column structure, and concentrations of dissolved oxygen, nitrate, inorganic carbon species, and particulate matter. They document the presence of phytoplankton blooms and export, zooplankton abundance and vertical migration, the presence of Arctic cod and other fishes, and the vocalizations of marine mammals. The CEO is designed to monitor the ecosystem year-round, making it well-suited for studying interactions among ecosystem components, especially during the poorly documented winter months. Although to our knowledge, no other single Arctic monitoring site measures the full suite of variables collected by the CEO, of course many of the individual measurements are also made elsewhere across the Arctic. With time, we expect that insights derived from the CEO observations will be extended to other Arctic shelf ecosystems and trigger new comparative studies.

\section{The Chukchi seascape}

The artist's depiction of the Hanna Shoal ecosystem (Fig. 3) illustrates the seasonal cycle at the CEO site (Fig. 3A). Moving from left to right, Fig. 3 captures seasonal shifts from the ice-covered winter, into the productive summer, and finally into the stormy and biologically senescent autumn.

Through heat loss, sea ice formation, and brine rejection (Fig. 3B) in late fall and winter, the water column over the Chukchi Shelf becomes more saline and vertically homoge- 
nized (Weingartner et al., 2005), deepening the mixed layer depth to a maximum of $\sim 36 \mathrm{~m}$ in March (Peralta-Ferriz and Woodgate, 2015). Although nutrients are in abundant supply from the incoming Anadyr-origin waters, planktonic production remains limited due to the scarcity of light (Fig. 3C). Over the course of winter, continued heat loss to the atmosphere leads to thermodynamic thickening of the sea ice, while convergence of the ice pack leads to mechanical thickening in the form of pressure ridges. Divergence of the ice pack creates open water in the form of leads and polynyas, which during winter will freeze and thicken through the same processes. As the light begins to return in the spring, diatoms and other algae begin to bloom within the ice matrix and at the ice-water interface (Fig. 3D; Ambrose et al., 2005; Gradinger, 2009).

It is not until late May or June, when the days are long, insolation is strong, and warm water moves in from the south that sea ice begins to melt, thin, and recede northwards (Fig. 3E). During this time, the water column stratifies with inputs of fresh meltwater and heat at the surface (Fig. 3G), leading to a shoaling of the mixed layer depth to a minimum of $\sim 12 \mathrm{~m}$ (Peralta-Ferriz and Woodgate, 2015). This is the time when extraordinary phytoplankton blooms occur in the nutrient-rich surface waters (Fig. 3F; Hill et al., 2018). These processes set up strong vertical gradients of inorganic carbon and nutrients across the shallow water column (Fig. 3H; Bates, 2006). These high rates of primary production support large fluxes of sinking particulate organic matter to the seafloor (Fig. 3I, Lalande et al., 2007), thereby sustaining a rich benthic ecosystem (Fig. 3J; Grebmeier et al., 2006, 2015), which attracts large numbers of marine mammals that forage on the benthos (Fig. 3K; Jay et al., 2012; Hannay et al., 2013) or Arctic cod (Fig. 3L).

Fall is characterized by surface cooling and more frequent and intense storm systems with strong winds (Fig. 3M) that erode the highly stratified water column. This process brings remineralized nutrients and inorganic carbon from bottom waters into the surface layer, supporting fall phytoplankton blooms and the outgassing of carbon dioxide into the atmosphere (Else et al., 2012; Hauri et al., 2013). Later, as sunlight fades into the darkness of winter, primary production further slows, the planktonic ecosystem becomes senescent (Fig. 3N), and the benthos continues to thrive on organic matter stored in the sediments (Pirtle-Levy et al., 2009).

Due to the logistical complexities of operating in the region, most of the observational work done in the Pacific sector of the Arctic Ocean takes place during the sea-ice-free summer and early autumn via research vessels (Fig. 3O). Autonomous vehicles such as gliders have also found increasing use in recent years (Fig. 3P; Baumgartner et al., 2014; Martini et al., 2016; Danielson et al., 2017).

\section{Arctic observing challenges}

A starting premise of our effort to improve the understanding of this complex ecosystem and monitor ongoing changes is that it is necessary to extend observations of the ecosystem into the ice-covered winter and employ new observational approaches that are appropriate for this challenging environment.

Given the presence of deep ice keels that regularly exceed $20 \mathrm{~m}$ depth - and may occasionally extend as deep as $30 \mathrm{~m}-$ we restrict the uppermost sensor package of our observatory to $33 \mathrm{~m}$ below the surface, leaving only $12 \mathrm{~m}$ of the water column safe for mooring instrumentation and hardware. Although we cannot deploy instruments in the upper $30 \mathrm{~m}$ of the water column when sea ice is present, upward looking acoustic instruments in the array provide observations above the top-mooring package. An Acoustic Zooplankton Fish Profiler (AZFP, manufactured by ASL Environmental Sciences) measures the presence and abundance of zooplankton and fish and ice draft, while a TeledyneRDI Acoustic Doppler Current Profiler (ADCP) records current velocity and direction. During sea-ice-free conditions, the ADCP instrument also quantifies the height, period, and direction of surface waves.

One example of purpose-built technology for the CEO is a novel "freeze-up detection mooring", which measures upper water column stratification and heat content through the fall up to the time of freeze-up in ice-covered seas (Fig. 4c). It was first deployed in fall 2015. The freeze-up detection mooring was outfitted with an expendable surface float that housed a satellite communications package, a tether release, an inductive modem, and a sea surface temperature sensor. The surface float was connected to four Sea-Bird SBE 37 inductive modem conductivity-temperature-depth sensors (CTDs) that transmitted hourly temperature, salinity and pressure to the surface float from four subsurface depths $(8,20,30$, and $40 \mathrm{~m})$, along with a subsurface camera that records and sends digital images of the upper water column. The advance of the fall ice pack was closely monitored with satellite imagery and the surface float provided simultaneous real-time monitoring of the temperature and salinity throughout the water column leading up to ice formation. When the ice edge was within 1 day of overrunning the mooring and sparse ice chunks were already floating by, the surface float was remotely released from the mooring, leaving a mid-depth subsurface float to provide floatation for the portion left behind. The data from this mooring are presented and discussed below (Fig. 5).

Cold seawater (temperatures below $0{ }^{\circ} \mathrm{C}$ for most of the year) decreases the capacity of all batteries. Some instruments are powered with lithium batteries that provide a higher power density. Engineering constraints dictate the trade-offs between the various sensor battery packs and the desired sampling rates. For example, due to the large power demand of the Kongsberg Contros HydroC $p \mathrm{CO}_{2}$ sensor, its 


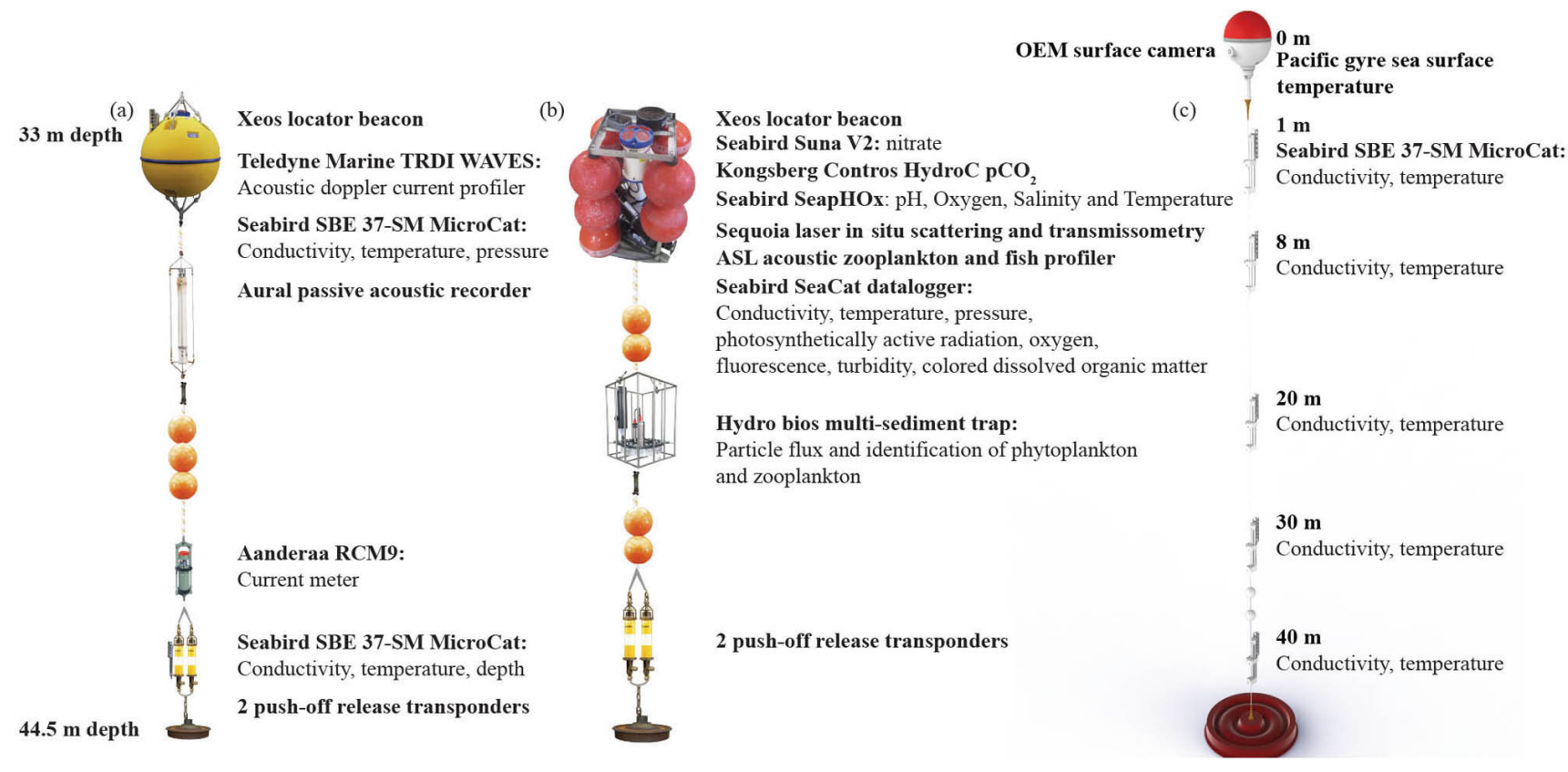

Figure 4. Illustration of the Chukchi Ecosystem Observatory (CEO), including the (a) biophysical, (b) biogeochemical, and (c) freeze-up moorings. Note that the freeze-up mooring includes a surface package, whereas the other two moorings only reach up to $33 \mathrm{~m}$ depth. Sensors are calibrated with as many in situ samples as possible. Calibration samples are always collected upon deployment and recovery of the moorings and, depending on other research activity nearby our site, also at other times of the year. $p \mathrm{CO}_{2}$ and $\mathrm{pH}$ sensors were added in summer 2016.

sampling rate had to be decreased to once every $12 \mathrm{~h}$ but the AZFP instrument has sufficient power and memory to sample every $15 \mathrm{~s}$ for the entire year.

A dedicated vessel charter for servicing the remote CEO is also not cost-effective given the $2000 \mathrm{~km}$ distance to the nearest deep water, year-round ice-free port Dutch Harbor in Unalaska, Alaska. We thereby rely on vessels of opportunity during the summer months to deploy and recover the CEO as part of other funded shipboard research. By partnering with other oceanographic research teams that are operating in the region, we are also able to collect water samples from the CEO site to provide for in situ calibration of sensors throughout the deployment. Furthermore, ship-based observational efforts such as the Arctic Marine Biodiversity Observatory Network and the DBO programs add spatial context to the CEO data. Conversely, the CEO can help place research cruise data into a broader temporal context, including variability on scales ranging from the synoptic to the interannual (Danielson et al., 2017).

Despite design advances and features, limitations and challenges still remain to be overcome. For example, without real-time data communication capabilities, instrument function and data returns can only be assessed annually following the CEO turnaround. This delays data availability and makes the approach poorly suited for adaptive sampling efforts after deployment. Furthermore, throughout the winter, there are currently no ship-based efforts or autonomous ve- hicles operating in the region. The result is limited spatial context during winter and early spring, and an inability to collect samples for frequent calibrations of the CEO's deployed sensors. Many of the measurements made from the $\mathrm{CEO}$ are collected at a single depth within the water column, thus limiting the interpretation of upper water column variables, especially over the winter months. Future innovations and investments in technologies such as profiling winches, direct-to-shore submarine cable communications, or underice autonomous assets are a few possibilities that could mitigate some of these challenges.

\section{First scientific results}

The 2015-2016 data returns from the CEO provide a unique window into the year-round Arctic marine ecosystem (Fig. 6). We also present new data showing water column turnover and cooling processes during the freeze-up period (Figs. 5 and 6).

The physical conditions measured at the CEO include currents, waves, temperature, salinity, ice draft, and light (photosynthetic active radiation, PAR) (Figs. 5 and $6 \mathrm{a}-\mathrm{d}$ ). The temperature and salinity cycles are tied to lateral advection, surface heat fluxes, ice cover, and winds. Sensors on the freezeup detection buoy show that the upper $20 \mathrm{~m}$ of the water column was well mixed and steadily lost heat from around $4^{\circ} \mathrm{C}$ at the beginning of September to $-1.5^{\circ} \mathrm{C}$ shortly be- 

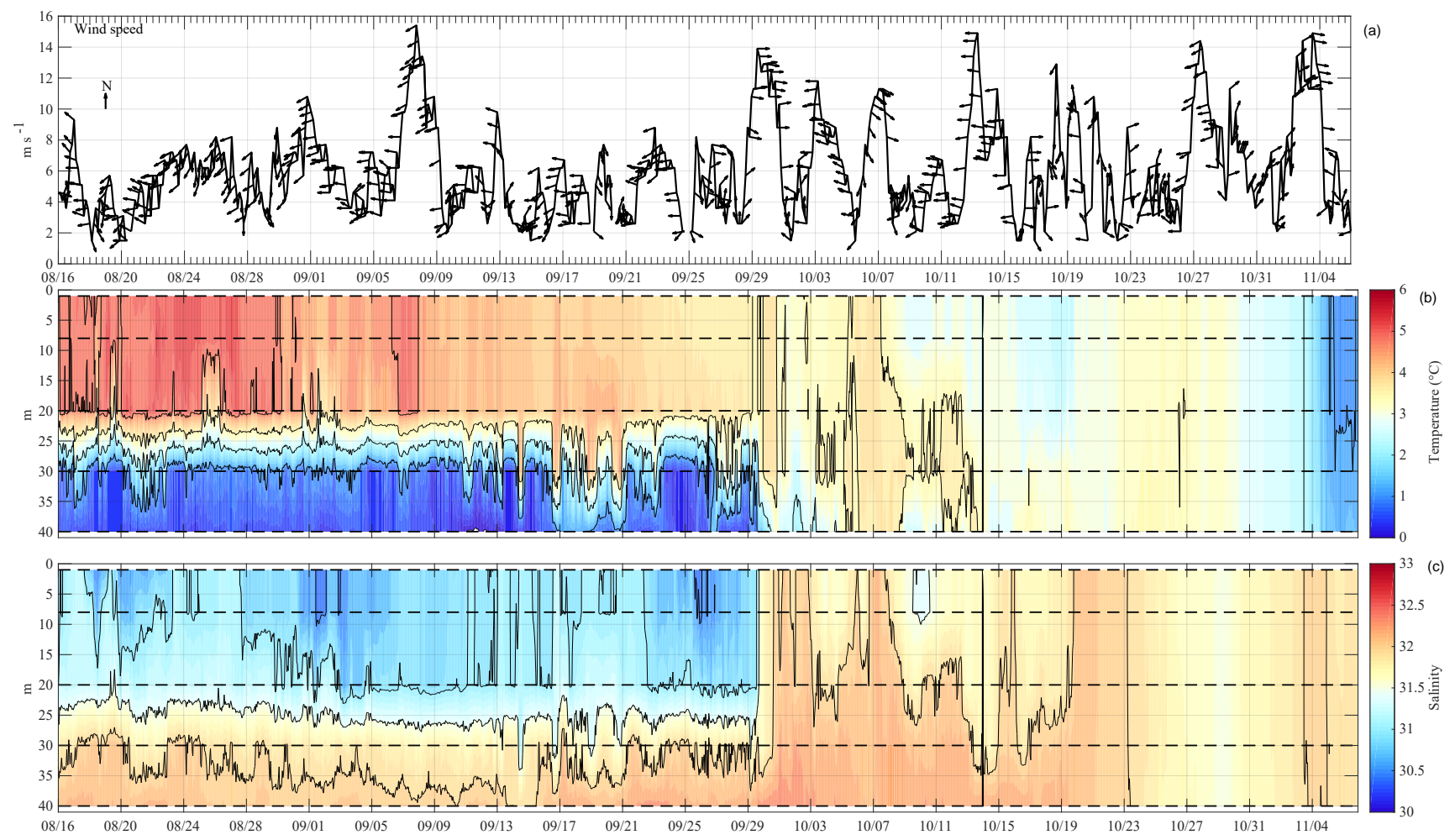

Figure 5. Time series from the NOAA-operated Wiley Post-Will Rogers Memorial Airport weather station and the Chukchi Ecosystem Observatory freeze-up detection mooring deployment in 2015. Shown are (a) wind speed and direction (arrows pointing downwind), (b) temperature $\left({ }^{\circ} \mathrm{C}\right)$, and (c) salinity. Conductivity and temperature sensors were moored at 8, 20, 30, and $40 \mathrm{~m}$ (dashed lines) from early September until close to freeze-up at the beginning of November.

fore sea ice formed at the beginning of November (Fig. 5). Water temperature at $30 \mathrm{~m}$ depth largely followed bottom water $(40 \mathrm{~m})$ temperature during September and early October. However, several large departures when 20 and $30 \mathrm{~m}$ temperatures briefly warmed and even exceeded those at the surface could indicate the effects of lateral advection and/or the passing influence of intra-pycnal eddies (Lu et al., 2015). The bottom water temperature steadily increased from $-1.5^{\circ} \mathrm{C}$ at the end of September to $1^{\circ} \mathrm{C}$ during freeze-up at the beginning of November, reversing the vertical temperature gradient in mid-October. Between September and November wind speeds in excess of $10 \mathrm{~m} \mathrm{~s}^{-1}$ were observed during the passage of several low-pressure systems (Fig. 5a). At peak intensity, these storm events did not appear to erode stratification at the CEO site. However, wind direction reversals, from predominantly upwelling-favorable directions (northeasterly) to downwelling-favorable directions (southwesterly), were associated with periodic depressions of the pycnocline. After freeze-up, water temperatures at the 34 and $43 \mathrm{~m}$ depths remained near the freezing point $\left(-1.6\right.$ to $\left.-1.8^{\circ} \mathrm{C}\right)$ through the end of the record in August.

Salinity followed a more cyclical progression of freshening between June and November and salinization in the other half of the year. Ice cover persisted for nearly 9 months
(November through August), and the thermodynamic thickening and thinning of the ice can be seen in the overall shape of the ice draft time series (Fig. 6a). Some ice keels extended to deeper than $10 \mathrm{~m}$ below the surface, although an ice draft of 1-3 $\mathrm{m}$ was more typical. The absence of deeper keels may be due to the upwind proximity of Hanna Shoal, which would likely block or deflect deep-keeled ridges from the northeast. At the same time, the absence of extended midwinter periods of open water demonstrates that the CEO lies outside any polynya formation zone due to the proximity of the shallow Hanna Shoal.

Nitrate is the limiting nutrient in the Chukchi Sea (Walsh et al., 1989) and therefore is an important bottom-up control for the ecosystem. We deployed a SUNA V2 nitrate sensor (Sea-Bird Scientific) on the upper instrument package ( $34 \mathrm{~m}$ below the surface; Fig. 6e). Over 26-28 August 2015 , shortly after deployment, nitrate values dropped from above $15 \mu \mathrm{M}$ down to between 5 and $7.5 \mu \mathrm{M}$ during a strong and prolonged storm. Nearby shipboard wind measurements exceeded $10 \mathrm{~m} \mathrm{~s}^{-1}$ for part of each day from 25 to $29 \mathrm{Au}-$ gust 2015. The drop in nitrate concentrations was simultaneous with a sharp increase in bottom water temperatures (Fig. 6c) and an increase in dissolved oxygen (Fig. 6f), likely indicating that strong mixing of surface waters with warm, 


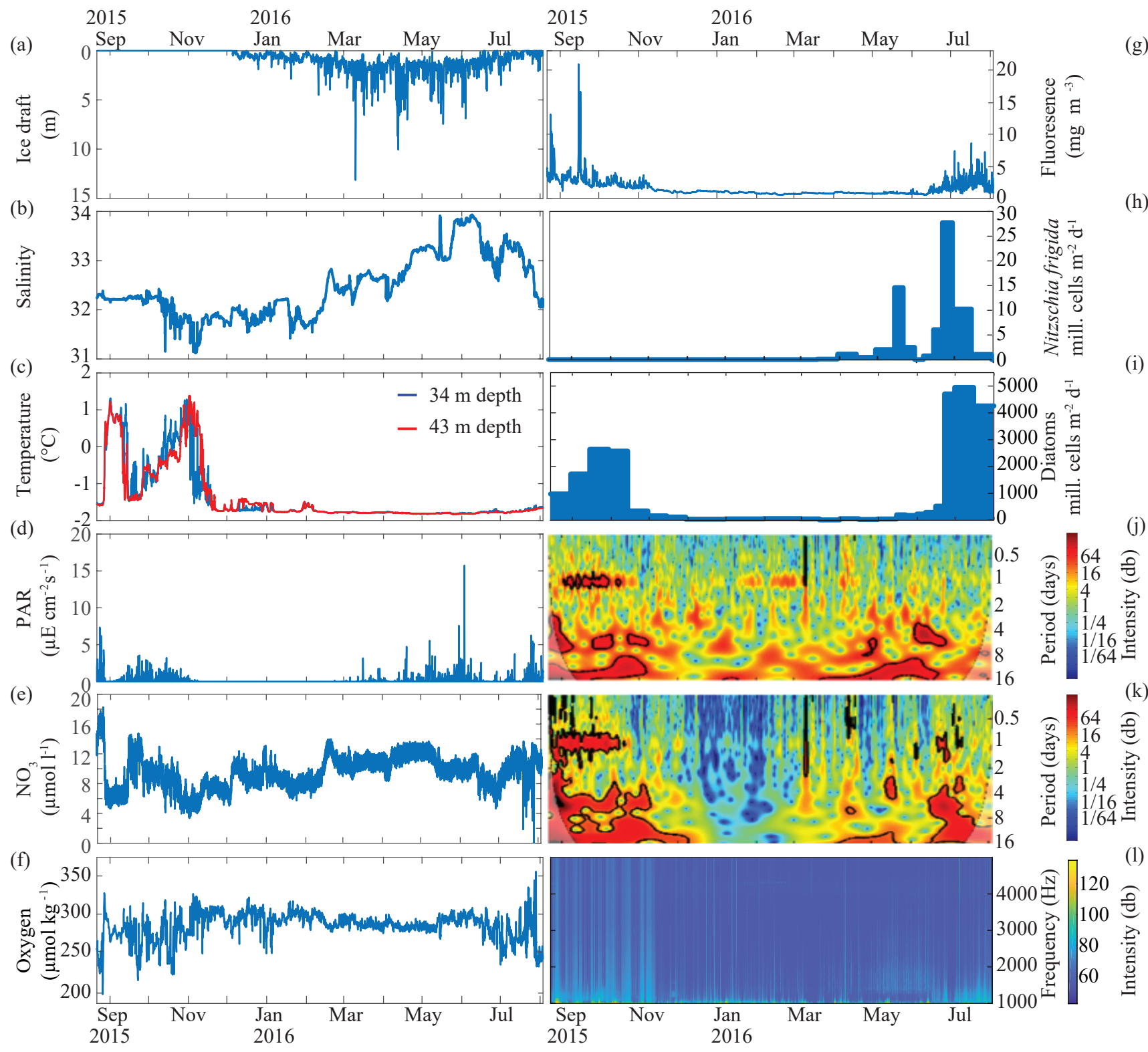

Figure 6. Data from the 2015/16 deployment. Shown are (a) ice draft (m), (b) salinity, (c) temperature $\left({ }^{\circ} \mathrm{C}\right)$, (d) photosynthetically active radiation (PAR, $\left.\mu \mathrm{Ecm}^{-2} \mathrm{~s}^{-1}\right)$, (e) nitrate $\left(\mathrm{NO}_{3}, \mu \mathrm{molL} \mathrm{L}^{-1}\right)$, (f) oxygen $\left(\mathrm{O}_{2}, \mu \mathrm{mol} \mathrm{kg}{ }^{-1}\right)$, (g) fluorescence $\left(\mathrm{mg} \mathrm{m}^{-3}\right)$, Nitzschia frigida flux (million cells $\mathrm{m}^{-2} \mathrm{~d}^{-1}$ ), (i) diatoms (million cells $\mathrm{m}^{-2} \mathrm{~d}^{-1}$ ), (j) acoustic zooplankton fish profiler (AZFP, days) $125 \mathrm{KHz}$, (k) AZFP $38 \mathrm{KHz}$ (days), and (l) acoustic spectra (Hz). In situ $\mathrm{NO}_{3}$ water samples were collected at times of the CEO deployment and recovery and were analyzed with standard wet chemical determinations of nitrate + nitrite of frozen samples at the Chesapeake Biological Laboratory. Using the calibration samples as anchor points, a drift of $12 \mu \mathrm{molL}^{-1}$ throughout the deployment was found and corrected by linearly detrending the data.

nutrient-depleted, and oxygen-rich waters down to the depth of the sensors. Nitrate and temperature remained relatively constant for a couple of weeks before returning to higher and lower values, respectively, in the middle of September. While dissolved oxygen concentrations increased slowly from midSeptember until freeze-up, nitrate concentrations declined as water column stratification weakened and overturning was initiated (Fig. 5) due to the strong heat and buoyancy losses from the surface ocean. These coincident changes indicate that the decline in nitrate during this time period was driven in part by the dilution of bottom water nitrate with low-nitrate surface waters, although some fall production also occurred at this time: chlorophyll $a$ fluorescence at the CEO was measurable through at least early November (Fig. 6g). Follow- 
ing freeze-up, nitrate concentrations slowly increased from a low of approximately $5 \mu \mathrm{M}$ in early November to $12 \mu \mathrm{M}$ in early May. These increases and the anticorrelated decrease in dissolved oxygen reflect the ongoing remineralization of organic matter in sediments and the water column throughout the winter.

Chlorophyll $a$ fluorescence and sediment trap collections reveal a seasonal cycle of phytoplankton and ice algae export from surface waters. Large chlorophyll $a$ peaks were observed in August and September. In June, chlorophyll $a$ fluorescence increased from a low wintertime background level and remained elevated with intermittent peaks throughout the summer. Because the sensor is located below the summer mixed layer, it is not well situated to record the phytoplankton that resides within the upper water column or within/under the ice. However, the identification of sediment trap contents indicates that Nitzschia frigida, an iceobligate pennate diatom, began sinking from the ice as early as April, with large pulses in May and June (Fig. 6h). During these times, sea ice and surface snowmelt would have begun, a process that would flush diatoms out of the ice matrix. Large quantities of phytoplankton were also collected in the traps in September/October and June/July, correlating with the chlorophyll $a$ peaks, suggesting blooms in spring and fall.

Wavelet analysis of the AZFP acoustic backscatter at $125 \mathrm{kHz}$ indicated a strong diurnal (1-day period) signal (Fig. 6j). This diurnal signal was found in open-water conditions in fall when the zooplankton undergo daily migrations up and down in the water column. More surprisingly, there were also strong indications of diurnal migrations in midwinter (January to March) under ice cover. In the spring, backscatter at $125 \mathrm{kHz}$ was present but not strongly associated with diurnal migration.

The $38 \mathrm{kHz}$ active acoustic data suggest a strong diurnal migration of fish with swim bladders from August into October, diminished backscatter from December to February, and then higher background levels with intermittently strong returns in April through July (Fig. 6k).

The passive acoustic spectra reveal the timing and source of underwater sounds, notably bearded seal vocalizations in spring and early summer (Fig. 61).

\section{Concluding thoughts}

Over the past several decades, moorings have been deployed at select sites across the Arctic as tools for providing insights into the year-round functioning of this system (e.g., Woodgate et al., 2012; Nishino et al., 2016; Polyakov et al., 2017; de Jong et al., 2018). These moorings are usually outfitted with sensors to measure physical properties and, less frequently, biological and geochemical samplers, such as nitrate sensors and sediment traps. To obtain a better understanding of polar ecosystems, ship-based biological and geochemical sampling often complements moored observatories (e.g., Southern Ocean Observing System, Fram Strait Arctic Outflow Observatory). Much has been learned from these endeavors, especially with regard to water mass circulation and the functioning of the ecosystem and biological pump (e.g., Forest et al., 2013; Kenitz et al., 2017; Eriksen et al., 2018). The CEO adds a highly outfitted complement of acoustic, optical, electrochemical, and gas membrane sensors as well as direct sample collection devices. In doing so, the CEO dataset illuminates multiple linkages of the physical, chemical, and biological environment. This broad suite of observations represents a necessary but mostly untried approach to integrated ecosystem research and monitoring in the Arctic. To our knowledge, the CEO is the most extensive moored observatory for the continuous recording of ecosystem variables in an ice-covered sea.

The Arctic has already undergone and will continue to undergo transformative physical and chemical changes. Such changes may trigger a cascade of consequences that propagate into the regional ecosystem and may test its resiliency and vulnerability. The extensive year-round dataset derived from the CEO is providing insights into how the ecosystem operates, covering physical, chemical, and biological processes. These baseline data also offer quantitative comparisons in future years for assessing ecosystem responses to an altered climate. Even though a distinction of secular trends from natural interannual, decadal, and seasonal variability will require a time series of around 40 years in high-latitude regions (Henson et al., 2010), gaining a better understanding of the system's current state and mechanisms that govern its variability is a necessary first step towards that goal. The data from the observatory are available to improve biogeochemical and ecological models that allow us to test, analyze, and prepare for the future. The status and trends in the marine ecosystem of the northeastern Chukchi Sea, observed through seasonal ship field programs, moorings such as the $\mathrm{CEO}$, and satellite observations will provide critical information on the status of the ecosystem and associated ecosystem services it can provide. For example, local subsistence users are interested in a healthy food web that supports traditional food sources. Reduced sea ice may increase the potential of the northward migration of subarctic species, including commercial fish species that will alter those food webs (Frainer et al., 2017). The CEO will allow year-round tracking of the marine ecosystem in the northeastern Chukchi Sea and thus can provide data valuable to an ecosystem-based approach to resource management.

Arctic changes, including human-induced influences on climate, are expected to affect high-latitude food webs. A better understanding of the driving factors of potential ecosystem shifts can only be gained through coordinated and simultaneous measurements such as these that span a wide range of physical, chemical, and biological indicators. Quickly arising issues such as ocean acidification, warming, freshening, and deoxygenation require interdisciplinary ef- 
forts. While ship-based multidisciplinary efforts remain valuable components of observing efforts, these only provide episodic data coverage. On the other hand, continuous timeseries moorings generally do not include a large array of disciplines (Newton et al., 2015). The model of extensive ecosystem observation capabilities that the CEO provides can be used in other ecosystems beyond the challenging Arctic environment. For example, an ecosystem observatory for the Gulf of Alaska in the subarctic Pacific is currently being developed and is using some of the lessons learned here.

Data availability. Post-processed data are available through http: //www.chukchiecosystemobservatory.org/ (last access: 9 November 2018) and http://www.aoos.org (last access: 9 November 2018). Data from the ice detection buoy are available at https://portal. aoos.org/old/arctic\#metadata/75373/station (last access: 9 November 2018). This is NPRB publication no. 678 .

Author contributions. SD developed and designed the CEO. $\mathrm{CH}$, SD, AMPM, RRH, PW, PS, CL, KMS, HS, and JKH maintain instrumentation on the observatory. PS built and deployed the observatory. KM created the artwork in collaboration with $\mathrm{CH}, \mathrm{SD}$, and AMPM. $\mathrm{CH}$ prepared the paper with contributions from all coauthors.

Competing interests. The authors declare that they have no conflict of interest.

Acknowledgements. A broad consortium of academic, agency, and industry partners are contributing to the success of the CEO program. Major financial support comes from the National Pacific Research Board Long-term Monitoring (NPRB LTM) program (project no. 1426), the Alaska Ocean Observing System (award no. NA11NOS0120020), and the University of Alaska Fairbanks. Additional partners include the University of Washington, Universite Laval, Olgoonik-Fairweather, LLC. Claudine Hauri acknowledges support from the National Science Foundation Office of Polar Programs (OPP-1603116). Projects that serviced the CEO and/or collected water column calibration data were funded by the National Science Foundation, Bureau of Ocean Energy Management, National Oceanic and Atmospheric Administration, National Oceanographic Partnership Program, and Shell Exploration and Production Company, Inc. The primary goal of the NPRB LTM is to support time-series research and thereby improve the predictability of ecosystem responses to changing ocean conditions. Maintenance and calibration of our remote observatory is only possible due to numerous collaborators within the Arctic research community who helped with CEO deployment and recovery or collected sensor calibration samples. We would therefore like to thank Carin Ashjian, Jessica Cross, Miguel Goñi, Burke Hales, Katrin Iken, Laurie Juranek, Calvin Mordy, and Robert Pickart.

Edited by: Mario Hoppema

Reviewed by: Ruth Eriksen and one anonymous referee

\section{References}

Ambrose, W. G., Von Quillfeldt, C., Clough, L. M., Tilney, P. V. R., and Tucker, T.: The sub-ice algal community in the Chukchi sea: Large- and small-scale patterns of abundance based on images from a remotely operated vehicle, Polar Biol., 28, 784-795, https://doi.org/10.1007/s00300-005-0002-8, 2005.

Arrigo, K. R., Perovich, D. K., Pickart, R. S., Brown, Z. W., van Dijken, G. L., Lowry, K. E., Mills, M. M., Palmer, M. A., Balch, W. M., Bates, N. R., Benitez-Nelson, C. R., Brownlee, E., Frey, K. E., Laney, S. R., Mathis, J., Matsuoka, A., Mitchell, B. G., Moore, G. W. K., Reynolds, R. A., Sosik, H. M., and Swift, J. H.: Phytoplankton blooms beneath the sea ice in the Chukchi Sea, Deep-Sea Res. Pt. II, 105, 1-16, https://doi.org/10.1016/j.dsr2.2014.03.018, 2014.

Barrett, S. A. and Stringer, W. J.: Growth Mechanisms of "Katie's Floeberg," Arct. Alp. Res., 10, 775, https://doi.org/10.2307/1550744, 1978.

Bates, N.: Air-sea $\mathrm{CO}_{2}$ fluxes and the continental shelf pump of carbon in the Chukchi Sea adjacent to the Arctic Ocean, J. Geophys. Res., 111, C10013, https://doi.org/10.1029/2005JC003083, 2006.

Baumgartner, M. F., Stafford, K. M., Winsor, P., Statscewich, H., and Fratantoni, D. M.: Glider-based passive acoustic monitoring in the Arctic, Mar. Technol. Soc. J., 48, 40-51, https://doi.org/10.4031/MTSJ.48.5.2, 2014.

Bintanja, R. and Selten, F. M.: Future increases in Arctic precipitation linked to local evaporation and sea-ice retreat, Nature, 509, 479-482, https://doi.org/10.1038/nature13259, 2014.

Corlett, W. B. and Pickart, R. S.: The Chukchi Slope Current, Prog. Oceanogr., 153, 50-65, https://doi.org/10.1016/j.pocean.2017.04.005, 2017.

Danielson, S. L., Cooper, L. W., Grebmeier, J. M., Hauri, C., Iken, K., Hopcroft, R. R., Horne, J. H., Lalande, C., McDonnell, A. M. P., Stafford, K. M., and Winsor, P.: Collaborative approaches to multi-disciplinary monitoring of the Chukchi shelf marine ecosystem, in: MTS/IEEE Oceans17 conference proceedings, Anchorage, AK, USA, 18-21 September 2017, IEEE, 1-7, 2017.

Day, R. H., Weingartner, T. J., Hopcroft, R. R., Aerts, L. A. M., Blanchard, A. L., Gall, A. E., Gallaway, B. J., Hannay, D. E., Holladay, B. A., Mathis, J. T., Norcross, B. L., Questel, J. M., and Wisdom, S. S.: The offshore northeastern Chukchi Sea, Alaska: A complex high-latitude ecosystem, Cont. Shelf Res., 67, 147165, https://doi.org/10.1016/j.csr.2013.02.002, 2013.

de Jong, M. F., Oltmanns, M., Karstensen, J., and de Steur, L: Deep Convection in the Irminger Sea observed with a dense mooring array, Oceanography, 31, 50-59, https://doi.org/10.5670/oceanog.2018.109, 2018.

Dunton, K. H., Grebmeier, J. M., and Trefry, J. H: The benthic ecosystem of the northeastern Chukchi Sea: An overview of its unique biogeochemistry and biological characteristics, Deep-Sea Res. Pt. II, 102, 1-8, https://doi.org/10.1016/j.dsr2.2014.01.001, 2014.

Else, B. G. T., Papakyriakou, T. N., Galley, R. J., Mucci, A., Gosselin, M., Miller, L. A., Shadwick, E. H., and Thomas, H.: Annual cycles of $p \mathrm{CO}_{2 \mathrm{sw}}$ in the southeastern Beaufort Sea: New understandings of air-sea $\mathrm{CO}_{2}$ exchange in arctic polynya regions, J. Geophys. Res., 117, C00G13, https://doi.org/10.1029/2011JC007346, 2012. 
Eriksen R., Trull, T. W., Davies, D., Jansen, P., Davidson, A.T., Westwood, K., and van den Enden, R.: Seasonal succession of phytoplankton community structure from autonomous sampling at the Australian Southern Ocean Time Series (SOTS) observatory, Mar. Ecol. Prog. Ser., 589, 13-31, https://doi.org/10.3354/meps12420, 2018.

Ershova, A. E., Hopcroft, R. R., and Kosobokova, K. N.: Interannual variability of summer mesozooplankton communities of the western Chukchi Sea: 2004-2012, Polar Biol., 38, 14611481, https://doi.org/10.1007/s00300-015-1709-9, 2015.

Evans, W., Mathis, J. T., and Cross, J. N.: Calcium carbonate corrosivity in an Alaskan inland sea, Biogeosciences, 11, 365-379, https://doi.org/10.5194/bg-11-365-2014, 2014.

Forest, A., Joint, T., Lalande, C., Hwang, J., Korea, S., and Sampei, M.: Bio-mooring arrays and long-term sediment traps: Key tools to detect change in the biogeochemical and ecological functioning of Arctic marine ecosystems, Arct. Obs. Summit 2013, 1-20, 2013.

Frainer, A., Primicerio, R., Kortsch, S., Aune, M., Dolgov, A. V., Fossheim, M., and Aschan, M. M.: Climate-driven changes in functional biogeography of Arctic marine fish communities, P. Natl. Acad. Sci. USA, 114, 12202-12207, https://doi.org/10.1073/pnas.1706080114, 2017.

Frey, K. E., Moore, G. W. K., Cooper, L. W., and Grebmeier, J. M.: Divergent patterns of recent sea ice cover across the Bering, Chukchi, and Beaufort seas of the Pacific Arctic Region, Prog. Oceanogr., 136, 32-49, https://doi.org/10.1016/j.pocean.2015.05.009, 2015.

Gradinger, R.: Sea-ice algae: Major contributors to primary production and algal biomass in the Chukchi and Beaufort Seas during May/June 2002, Deep-Sea Res. Pt. II, 56, 1201-1212, https://doi.org/10.1016/j.dsr2.2008.10.016, 2009.

Grebmeier, J. M., Cooper, L. W, Feder., H. M., and Sirenko, B. I.: Ecosystem dynamics of the Pacific-influenced Northern Bering and Chukchi Seas in the Amerasian Arctic, Prog. Oceanogr., 71, 331-361, https://doi.org/10.1016/j.pocean.2006.10.001, 2006.

Grebmeier, J. M., Bluhm, B. A., Cooper, L. W., Danielson, S. L., Arrigo, K. R., Blanchard, A. L., Clarke, J. T., Day, R. H., Frey, K. E., Gradinger, R. R., Kędra, M., Konar, B., Kuletz, K. J., Lee, S. H., Lovvorn, J. R., Norcross, B. L., and Okkonen, S. R.: Ecosystem characteristics and processes facilitating persistent macrobenthic biomass hotspots and associated benthivory in the Pacific Arctic, Prog. Oceanogr., 136, 92-114, https://doi.org/10.1016/j.pocean.2015.05.006, 2015.

Hakkinen, S., Proshutinsky, A., and Ashik, I.: Sea ice drift in the Arctic since the 1950s, Geophys. Res. Lett., 35, L19704, https://doi.org/10.1029/2008GL034791, 2008.

Hannay, D. E., Delarue, J., Mouy, X., Martin, B. S., Leary, D., Oswald, J. N., and Vallarta, J.: Marine mammal acoustic detections in the northeastern Chukchi Sea, September 2007-July 2011, Cont. Shelf Res., 67, 127-146, https://doi.org/10.1016/j.csr.2013.07.009, 2013.

Hauri, C., Winsor, P., Juranek, L. W., McDonnell, A. M. P., Takahashi, T., and Mathis, J. T.: Wind-driven mixing causes a reduction in the strength of the continental shelf carbon pump in the Chukchi Sea, Geophys. Res. Lett., 40, 5932-5936, https://doi.org/10.1002/2013GL058267, 2013.

Henson, S. A., Sarmiento, J. L., Dunne, J. P., Bopp, L., Lima, I., Doney, S. C., John, J., and Beaulieu, C.: Detec- tion of anthropogenic climate change in satellite records of ocean chlorophyll and productivity, Biogeosciences, 7, 621-640, https://doi.org/10.5194/bg-7-621-2010, 2010.

Hill, V., Ardyna, M., Lee, S.H., and Varela, D.E.: Decadal trends in phytoplankton production in the Pacific Arctic Region from 1950 to 2012, Deep-Sea Res. Pt. II, 152, 82-94, https://doi.org/10.1016/j.dsr2.2016.12.015, 2018.

Jay, C. V., Fischbach, A. S., and Kochnev, A. A.: Walrus areas of use in the Chukchi Sea during sparse sea ice cover, Mar. Ecol. Prog. Ser., 468, 1-13, https://doi.org/10.3354/meps10057, 2012.

Kenitz, K. M., Visser, A. W., Mariani, P., and Andersen, K. H.: Seasonal succession in zooplankton feeding traits reveals trophic trait coupling, Limnol. Oceanogr., 62, 1184-1197, https://doi.org/10.1002/lno.10494, 2017.

Kuletz, K. J., Ferguson, M. C., Hurley, B., Gall, A. E., Labunski, E. A., and Morgan, T. C.: Seasonal spatial patterns in seabird and marine mammal distribution in the eastern Chukchi and western Beaufort seas: Identifying biologically important pelagic areas, Prog. Oceanogr., 136, 175-200, https://doi.org/10.1016/j.pocean.2015.05.012, 2015.

Lalande, C., Grebmeier, J. M., Wassmann, P., Cooper, L. W., Flint, M. V., and Sergeeva, V. M.: Export fluxes of biogenic matter in the presence and absence of seasonal sea ice cover in the Chukchi Sea, Cont. Shelf Res., 27, 2051-2065, https://doi.org/10.1016/j.csr.2007.05.005, 2007.

Lu, K., Weingartner, T., Danielson, D., Winsor, P., Dobbins, E., Martini, K., and Statscewich, H.: Lateral mixing across meltwater fronts of the Chukchi Sea shelf, Geophys. Res. Lett., 42, 6754-6761, https://doi.org/10.1002/2015GL064967, 2015.

Martini, K. I., Stabeno, P. J., Ladd, C., Winsor, P., Weingartner, T. J., Mordy, C. W., and Eisner, L. B.: Dependence of subsurface chlorophyll on seasonal water masses in the Chukchi Sea, J. Geophys. Res.-Oceans, 121, 1755-1770, https://doi.org/10.1002/2015JC011359, 2016.

McCabe, G. J., Clark, M. P., and Serreze, M. C.: Trends in Northern Hemisphere Surface Cyclone Frequency and Intensity, J. Climate, 14, 2763-2768, https://doi.org/10.1175/15200442(2001)014<2763:TINHSC>2.0.CO;2, 2001.

McPhee, M. G., Proshutinsky, A., Morison, J. H., Steele, M., and Alkire, M. B.: Rapid change in freshwater content of the Arctic Ocean, Geophys. Res. Lett., 36, L10602, https://doi.org/10.1029/2009GL037525, 2009.

Moore, S. E. and Grebmeier, J. M.: The Distributed Biological Observatory: Linking Physics to Biology in the Pacific Arctic Region, Arctic, 71, 1-7, https://doi.org/10.14430/arctic4606, 2018.

Morison, J., Kwok, R., Peralta-Ferriz, C., Alkire, M., Rigor, I., Andersen, R., and Steele, M.: Changing Arctic Ocean freshwater pathways, Nature, 481, 66-70, https://doi.org/10.1038/nature10705, 2012.

Newton, J. A., Feely, R. A., Jewett, E. B., Williamson, P., and Mathis J.: Global Ocean Acidification Observing Network: Requirements and Governance Plan, 2nd edn., GOA-ON, available at: http://goa-on.org/documents/resources/GOA-ON_2nd_ edition_final.pdf (last access: 9 November 2018), 2015.

Nishino, S., Kikuchi, T., Fujiwara, A., Hirawake, T., and Aoyama, M.: Water mass characteristics and their temporal changes in a biological hotspot in the southern Chukchi Sea, Biogeosciences, 13, 2563-2578, https://doi.org/10.5194/bg-13-2563-2016, 2016. 
Orr, J. C.: Recent and future changes in ocean carbonate chemistry, in: Ocean Acidification, vol. 2, edited by: Gattuso, J.-P. and Hansson, L., Oxford University Press, Oxford, 41-66, 2011.

Peralta-Ferriz, C. and Woodgate, R. A.: Seasonal and interannual variability of pan-Arctic surface mixed layer properties from 1979 to 2012 from hydrographic data, and the dominance of stratification for multiyear mixed layer depth shoaling, Prog. Oceanogr., 134, 19-53, https://doi.org/10.1016/j.pocean.2014.12.005, 2015.

Pickart, R. S., Schulze, L. M., Moore, G. W. K., Charette, M. A., Arrigo, K. R., van Dijken, G., and Danielson, S. L.: Longterm trends of upwelling and impacts on primary productivity in the Alaskan Beaufort Sea, Deep-Sea Res. Pt. I, 79, 106-121, https://doi.org/10.1016/j.dsr.2013.05.003, 2013.

Pirtle-Levy, R., Grebmeier, J. M., Cooper, L. W., and Larsen, I. L.: Chlorophyll a in Arctic sediments implies long persistence of algal pigments, Deep-Sea Res. Pt. II, 56, 1326-1338, https://doi.org/10.1016/j.dsr2.2008.10.022, 2009.

Polyakov, I. V., Pnyushkov, A. V., Alkire, M. B., Ashik, I. M., Baumann, T. M., Carmack, E. C., Goszczko, I., Guthrie, J., Ivanov, V. V., Kanzow, T., Krishfield, T., Kwok, R., Sundfjord, A., Morison, J., Rember, R., and Yulin, A.: Greater role for Atlantic inflows on sea-ice loss in the Eurasian Basin of the Arctic Ocean, Science, 356, 285-291, https://doi.org/10.1126/science.aai8204, 2017.

Proshutinsky, A., Krishfield, R., Timmermans, M.-L., Toole, J., Carmack, E., McLaughlin, F., Williams, W. J., Zimmermann, S., Itoh, M., and Shimada, K.: Beaufort Gyre freshwater reservoir: State and variability from observations, J. Geophys. Res., 114, C00A10, https://doi.org/10.1029/2008JC005104, 2009.

Sambrotto, R. N., Goering, J. J., and McRoy, C. P.: Large yearly production of phytoplankton in the Western Bering Strait, Science, 225, 1147-1150, https://doi.org/10.1126/science.225.4667.1147, 1984.

Serreze, M. C. and Francis, J. A.: The Arctic amplification debate, Clim. Change, 76, 241-264, https://doi.org/10.1007/s10584005-9017-y, 2006.

Serreze, M. C. and Stroeve, J. C.: Arctic sea ice trends, variability and implications for seasonal ice forecasting, Philos. T. Roy. Soc. A, 373, 20140159, https://doi.org/10.1098/rsta.2014.0159, 2015.

Smith, T. M., Reynolds, R. W., Peterson, T. C., and Lawrimore, J.: Improvements NOAAs Historical Merged LandOcean Temp Analysis (1880-2006), J. Climate, 21, 2283-2296, https://doi.org/10.1175/2007JCLI2100.1, 2008.
Springer, A. M., McRoy, C. P., and Flint, M. V.: The Bering Sea Green Belt: shelf-edge processes and ecosystem production, Fish. Oceanogr., 5, 205-223, https://doi.org/10.1111/j.13652419.1996.tb00118.x, 1996.

Stigebrandt, A.: The North Pacific: A Global-Scale Estuary, J. Phys. Oceanogr., 14, 464-470, https://doi.org/10.1175/15200485(1984)014<0464:TNPAGS>2.0.CO;2, 1984.

Stocker, T. F., Qin, D., Plattner, G.-K., Tignor, M., Allen, S. K., Boschung, J., Nauels, A., Xia, Y., Bex, V., and Midgley, P. M.: IPCC: Climate Change 2013: The Physical Science Basis. Contribution of Working Group I to the Fifth Assessment Report of the Intergovernmental Panel on Climate Change, Cambridge University Press, Cambridge, United Kingdom and New York, NY, USA, 1535 pp., 2013.

Walsh, J. J., McRoy, C. P., Coachman, L. K., Goering, J. J., Nihoul, J. J., Whitledge, T. E., Blackburn, T. H., Parker, P. L., Wirick, C. D., Shuert, P. G., Grebmeier, J. M., Springer, A. M., Tripp, R. D., Hansell, D., Djenidi, S., Deleersnijder, E., Henriksen, K., Lund, B. A., Andersen, P., Müller-Karger, F. E., and Dean, K.: Carbon and nitrogen cycling within the Bering/Chukchi Seas: source regions for organic matter affecting AOU demands of the Arctic Ocean, Prog. Oceanogr., 22, 279361, https://doi.org/10.1016/0079-6611(89)90006-2, 1989.

Wassmann, P.: Arctic marine ecosystems in an era of rapid climate change, Prog. Oceanogr., 90, 1-17, https://doi.org/10.1016/j.pocean.2011.02.002, 2011.

Weingartner, T., Aagaard, K., Woodgate, R., Danielson, S., Sasaki, Y., and Cavalieri, D.: Circulation on the north central Chukchi Sea shelf, Deep-Sea Res. Pt. II, 52, 3150-3174, https://doi.org/10.1016/j.dsr2.2005.10.015, 2005.

Woodgate, R. A., Weingartner, T. J., and Lindsay, R.: Observed increases in Bering Strait oceanic fluxes from the Pacific to the Arctic from 2001 to 2011 and their impacts on the Arctic Ocean water column, Geophys. Res. Lett., 39, L24603, https://doi.org/10.1029/2012GL054092, 2012.

Yamamoto-Kawai, M., McLaughlin, F. A, Carmack, E. C., Nishino, S., and Shimada, K.: Aragonite undersaturation in the Arctic Ocean: effects of ocean acidification and sea ice melt, Science, 326, 1098-100, https://doi.org/10.1126/science.1174190, 2009. 